\title{
Streptomyces lividans groES, groEL1 and groEL2 genes
}

\author{
Patricia de León, ${ }^{1}$ Sergio Marco, ${ }^{1}$ Carolina Isiegas, ${ }^{1}$ Anabel Marina, ${ }^{2}$ \\ José L. Carrascosa' and Rafael P. Mellado'
}

Author for correspondence: Rafael P. Mellado. Tel: +34 1 5854547. Fax: +34 15854506.

e-mail: rpmellado@samba.cnb.uam.es

1 Centro Nacional de Biotecnología (CSIC),

Campus de la Universidad Autónoma, Cantoblanco, 28049 Madrid, Spain

2 Centro de Biología Molecular Severo Ochoa, Campus de la Universidad Autónoma, Cantoblanco, 28049 Madrid, Spain

\begin{abstract}
The Streptomyces lividans groESIEL1 operon and groEL2 gene were cloned and their respective DNA sequences determined. The sequenced DNA comprised the genes and their respective regulatory regions in both cases. Transcription of both groESIEL1 and groEL2 seemed to be subjected to temporal control at $30{ }^{\circ} \mathrm{C}$. At $45^{\circ} \mathrm{C}$ the amount of the groEL2 transcript increased considerably in comparison to that of groESIEL1. Among the proteins synthesized under heat shock by S. lividans, a fraction enriched in GroEL2 showed the presence of a ring-shaped structure that resembles that of other chaperonins and was active in a rhodanase folding assay.
\end{abstract}

Keywords: Streptomyces lividans, GroEL-like chaperones, heat shock

\section{INTRODUCTION}

Streptomyces is a genus that includes filamentous, Gram-positive bacteria with a complex life cycle that involves spore production and mycelium formation (Chater, 1984). Antibiotics, extracellular degradative enzymes and other secondary metabolites of broad industrial application begin to be produced at the transition between vegetative growth and the development of aerial mycelium (Berdy, 1980). Knowledge about physiology and growth control in streptomycetes is essential to fully understand and gain control of the production of these compounds of biotechnological importance.

All micro-organisms respond to an increase in the external temperature by inducing the expression of a reduced number of genes or sets of genes, which is known as the heat shock response. So far, very little is known about the overall regulation of the heat shock response in streptomycetes. GroEL-like proteins are heat-inducible, highly conserved from bacteria to eukaryotes and their function as molecular chaperones is indispensable (Craig et al., 1993). In S. albus and $S$. coelicolor the existence of two heat-inducible groEL genes has been reported (Mazodier et al., 1991; Duchene et al., 1994a). Among the streptomycetes, S. lividans is

The GenBank/EMBL/DDBJ accession numbers for the sequences reported in this paper are X95970 and X95971. almost exclusively used as a host for the cloning and expression of exogenous DNA because of the lack of an endonuclease restriction system (Kieser \& Hopwood, 1991). S. lividans is able to produce extracellular proteins in high amounts (Strickler et al., 1992) and glycosylate proteins (Hu et al., 1993), and has been broadly used for the production of proteins both of prokaryotic and eukaryotic origin. Successful overproduction of homologous and heterologous proteins might require a concomitant increase of production levels of cellular chaperones to properly stabilize the newly made polypeptides. In an attempt to further characterize the heat shock response and groEL genes, we cloned and sequenced the groEL genes from S. lividans and analysed their transcription level at different phases of cellular growth in both heat-shocked and untreated cultures.

\section{METHODS}

Bacterial strains, plasmids and culture methods. S. lividans TK21 (Hopwood et al., 1985) was used as source of chromosomal DNA. The plasmid pUC19 (Norrander et al., 1983) was propagated in Escherichia coli DH5 $\alpha$ (Hanahan, 1983) for DNA sequencing. Plasmid pRM1, a pRM1cat derivative from which the cat gene had been removed (Parro et al., 1991), was used as the vector to propagate the $S$. lividans chromosomal DNA in E. coli NM514 (Murray, 1983). Procedures for the growth and manipulation of Streptomyces and general recombinant DNA manipulation were as described by Hopwood et al. (1985) and Sambrook et al. (1989). For Streptomyces vector selection, thiostrepton (a gift of S. J. Lucania, Squibb Institute for Medical Research, Princeton, 
NJ, USA) was used at $50 \mu \mathrm{g} \mathrm{ml}^{-1}$ in agar and $10 \mu \mathrm{g} \mathrm{ml}^{-1}$ in broth cultures. For Southern blot hybridization, DNA probes were labelled with $\left[\alpha^{32} \mathrm{P}\right] \mathrm{dATP}$ using the Random Primed DNA Labelling Kit from Boehringer Mannhein, following the manufacturer's instructions. The radioactive probes were used to hybridize $S$. lividans genomic DNA fragments transferred to Hybond-N membrane (Amersham).

DNA sequencing. Sequencing of DNA was by the dideoxy chain-termination method (Sanger et al., 1977), using the 7deaza-dGTP reagent kit from USB following the manufacturer's recommendations. DNA ladders for the analysis of the $\mathrm{S} 1$ nuclease mapping experiments were sequenced by the same method.

In vitro transcription and RNA manipulations. RNA was isolated from $S$. lividans liquid cultures growing exponentially in NMMP medium at $30^{\circ} \mathrm{C}$ or heat-shocked at $45^{\circ} \mathrm{C}$ for $15 \mathrm{~min}$ (Marco et al., 1992) and prepared as described previously (Parro et al., 1991; Pulido et al., 1987). The cultures growing at $30^{\circ} \mathrm{C}$ made the transition to stationary phase around $40-42 \mathrm{~h}$ after inoculation. RNA was extracted from cultures at $30^{\circ} \mathrm{C}$ or after $15 \mathrm{~min}$ heat shock at $45^{\circ} \mathrm{C}$ at times coinciding with the four different growth phases identified for Streptomyces spp. (Puglia et al., 1995), designated RG1 (19 h), $\mathrm{T}(23 \mathrm{~h}), \mathrm{RG} 2(27 \mathrm{~h})$ and S (42 h). Hybridization conditions and $\mathrm{S} 1$ nuclease digestion were as described by Sambrook et al. (1989) and Barthelemy et al. (1986). The size values given for the S1 nuclease protected fragments were corrected by differential migration compared with the sequence ladder (Sollner-Webb \& Reeder, 1979). Total RNA for the colony hybridization was labelled with $\left[\gamma^{32} \mathrm{P}\right] \mathrm{ATP}$ in the presence of T4 polynucleotide kinase as described by Favaloro et al. (1980).

Computer analysis of sequences. The DNA sequence was analysed for ORFs using CODONPREFERENCE (University of Wisconsin Genetic Computer Group), with a Streptomyces codon usage table made from 64 sequenced genes (Wright $\&$ Bibb, 1992). Amino acid sequences were analysed using programs from the University of Wisconsin package (version 8.0 , September 1994). Sequences were compared with the EMBL database.

GroEL purification. Cells were grown under standard conditions (see above), heat-shocked at $45^{\circ} \mathrm{C}$ for $15 \mathrm{~min}$ during exponential growth, lysed and processed for GroEL purification as described by Carrascosa et al. (1990) and Marco et al. (1992), except that after lysis with alumina, the supernatant was batch incubated for $1 \mathrm{~h}$ at $4{ }^{\circ} \mathrm{C}$ with DEAE-cellulose equilibrated in buffer $A(1: 1, v / v)$ and the resin eliminated by low speed centrifugation prior to ammonium sulphate precipitation followed by $5-20 \%(\mathrm{w} / \mathrm{v})$ sucrose gradient centrifugation (Marco et al., 1992). Fractions from the gradient were tested by SDS-PAGE and electron microscopy to detect protein aggregates.

Western blotting and protein sequencing. Samples were fractionated by SDS-PAGE (Laemmli, 1970) in $10 \%(\mathrm{w} / \mathrm{v}$ ) polyacrylamide and transferred to an Immobilon-P membrane as described by Timmons \& Dunbar (1990). The transferred material was incubated with a 1:10000 dilution of rabbit polyclonal antibody raised against purified GroEL obtained from E. coli grown at $47^{\circ} \mathrm{C}$ (Carazo et al., 1991). The bands reacting with the antibody were further revealed by incubation with ${ }^{125}$ I-labelled protein A from Staphylococcus aureus (Amersham).

To obtain internal protein sequences, $5 \mu \mathrm{g}$ purified protein was subjected to SDS-PAGE, stained with Coomassie Blue and the $62 \mathrm{kDa}$ band was excised and digested with $1 \mu \mathrm{g}$ trypsin for $4 \mathrm{~h}$ as described by Rosenfeld et al. (1992). The resulting peptides were separated on a Vydac C18 $(250 \times 2.1 \mathrm{~mm})$ reverse phase column (Stone $\&$ Williams, 1993) and selected fractions were then applied onto polybrene-coated glass fibre filters and subjected to sequencing using an ABI 473A pulsedliquid phase protein sequencer (Applied Biosystems). To determine the $\mathrm{N}$-terminal protein sequence, $0.2 \mathrm{ml}$ purified protein (about $0.5 \mathrm{mg} \mathrm{ml}^{-1}$ ) was applied onto a PVDF membrane using a ProSpin cartridge (Applied Biosystems). After washing, the membrane was used directly for sequencing, employing the modified cycles according to manufacturer's instructions.

Folding activity measurement. Chaperonin folding activity was measured using the rhodanase assay as described by Llorca et al. (1994). Briefly, rhodanase (thiosulfate:cyanide sulfurtransferase, EC 2.8.1.1) from bovine liver (Sigma) was denatured in $8 \mathrm{M}$ guanidinium chloride and diluted 50-fold in buffer A, containing the samples to be analysed, $2 \mathrm{mM}$ ATP, $15 \mathrm{mM} \mathrm{MgCl}_{2}, 5 \mathrm{mM} \mathrm{KCl}, 1 \mathrm{mM}$ DTT and $70 \mathrm{mM} \mathrm{Na} \mathrm{S}_{2} \mathrm{O}_{3}$. Incubation was carried out at $37^{\circ} \mathrm{C}$. E. coli GroEL and GroES $(0 \cdot 2-0 \cdot 3 \mathrm{mM}$ each) were incubated under the same conditions as a positive control of the folding reaction. Rhodanase activity was measured as described by Westly (1981).

Electron microscopy. Samples were adhered to carbon-coated collodion grids and negatively stained with $2 \%(\mathrm{w} / \mathrm{v})$ uranyl acetate. Micrographs were taken in a JEOL 1200EX II electron microscope at $120 \mathrm{kV}$ and $50000 \times$ magnification.

\section{RESULTS}

\section{Cloning and sequencing of groES/EL1 and groEL2 genes}

Sets of oligonucleotides, derived from the conserved regions of the known DNA sequences of the $S$. coelicolor groES/EL1 operon (Duchene et al., 1994a), were used to synthesize specific DNA fragments from $S$. lividans

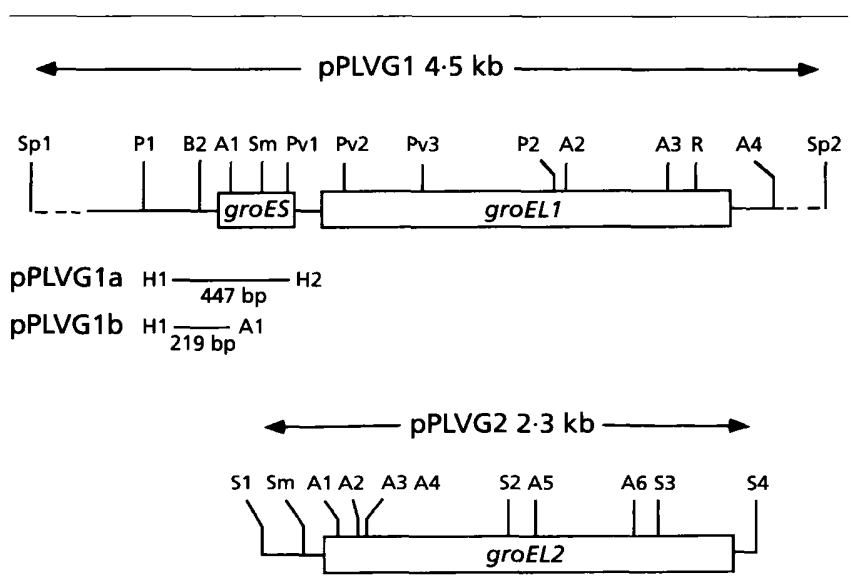

Fig. 1. Restriction map and genetic organization of the groES/EL1 (pPLVG1) and groEL2 (pPLVG2) regions. Inserts used for transcription initiation mapping, cloned into plasmids pUC18 or pUC19, are shown. Restriction sites employed for subcloning are indicated: A, Aval; B, BamHI; H, HindlII; P, Pstl; Pv, Pvul; R, Rsal; S, Sall; Sm, Smal; Sp, Sphl. 
(a)

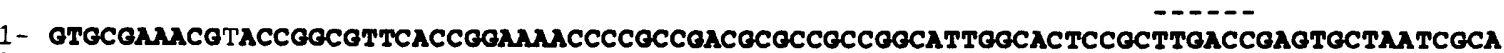

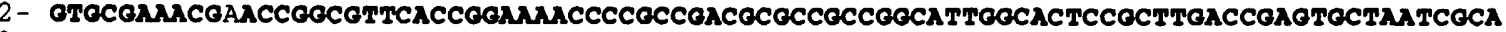

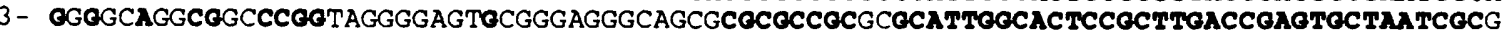

$-10$

$0-10$

$+1$

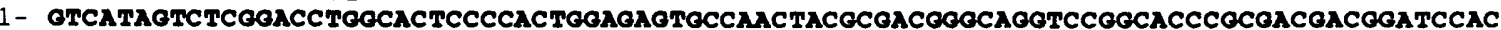

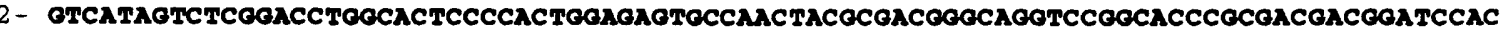

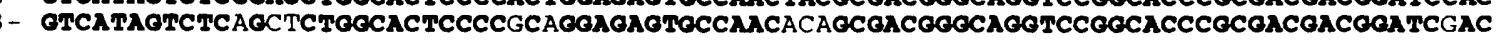
----->>

gross->

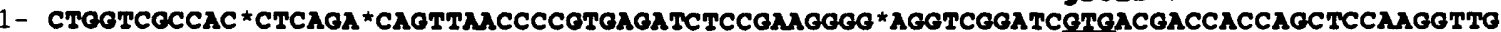

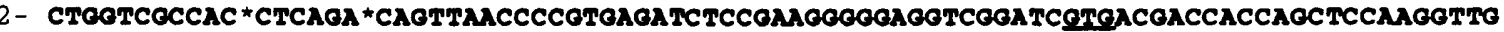

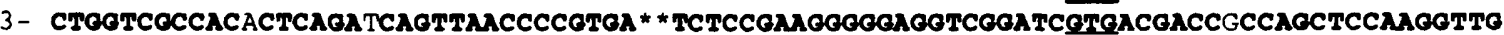

(b) $-35$

1- COOACOCCCOTCOTCCCOCTOTTCOCGGTTGCTGACCOGACGOCCCGATCCCCOGGAOOCGCTTOCACTCOACCATGCCOAGTG

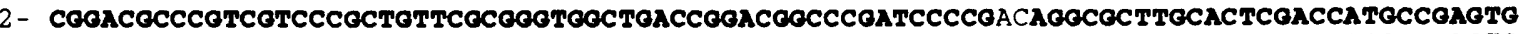

3- GCATCOCCGOCGCGGACAGGOCACCCCCAGTAAGACGGOCGCOOGCCOGAGGCCCCTAOCGCCTTOCACTCTCCTACCCCGATO $---\infty>-.-$

$-10$

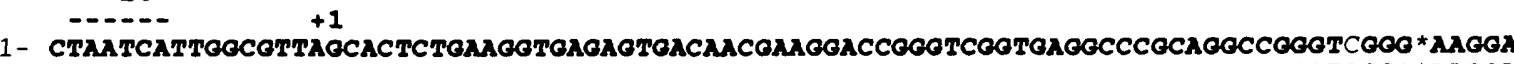

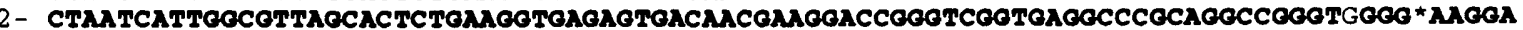

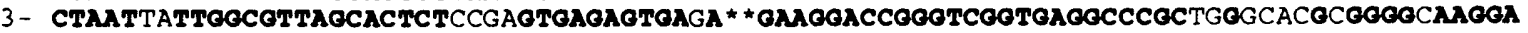

$----->$ <-----

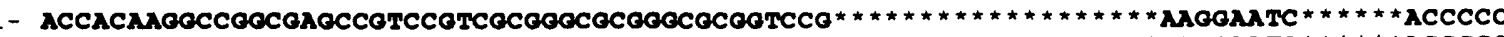

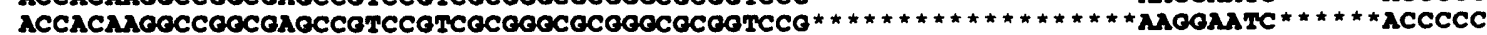
ACCGCGAGGCAGOCAGGCCOTCCOTCOCOQCCCCACCACQOTCCGGCGTATCCACCCTCCCCAGACAGAGTCCGGGGGACCCCC

GroEL2->

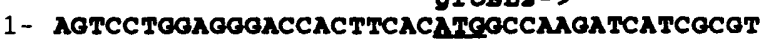

2 - AOTсCтоGA

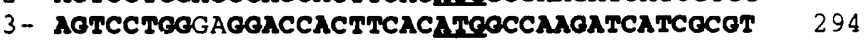

Fig. 2. Comparison of groES/EL1 (a) and groEL2 (b) regulatory regions of S. lividans (1) with that of S. coelicolor (2; Duchene et al., 1994a) and S. albus (3; Mazodier et al., 1991) from nt 102 (groES/EL1) and nt 1 (groEL2) from the S. coelicolor sequences as they appear in Duchene et al. (1994a). Identical nucleotides are indicated in bold. Putative - 35 and -10 regions relative to the $S$. lividans apparent transcription initiation sites $(+1)$, as determined by $S 1$ mapping, are indicated. CIRCE motifs are underlined with dashed arrows. Translation start codons are underlined. Asterisks indicate gaps in the sequence alignment.

genomic DNA by several cycles of PCR amplification. The oligonucleotides used were GRO-NC ( $5^{\prime}$ GACCGCCGCAAGGCGATG $3^{\prime}$ ) in combination with GRORC (5' GCCCTCCTCGACCGCGGC $\left.3^{\prime}\right)$ located at positions 1612-1629 and 1978-1995, respectively, in the case of groEL2, and R-PES (5' GGACGAGGTACTCCTCGC $3^{\prime}$ ) in combination with $\mathrm{N}^{*}$-PES ( $5^{\prime}$ GCATTGGCACTCCGCTTG $3^{\prime}$ ) or N-PES ( $5^{\prime}$ CCAAGGTTGCCATCAAGC $3^{\prime}$ ), located at positions 580-597, 151168 and 343-360, respectively, in the case of groES/EL1. Each oligonucleotide was constructed with HindIII restriction sites at each $5^{\prime}$ end. The amplified fragments were used as probes to screen a genomic library of $S$. lividans made in E. coli. Both the groES/EL1 operon and the groEL2 gene were cloned and their respective DNA sequences determined. A physical map of the cloned regions is shown in Fig. 1. The sequenced DNA contained the genes and their respective regulatory regions in both cases. The sequence of the regulatory regions is shown in Fig. 2.

\section{Southern analysis}

Different DNA probes were used in Southern blot hybridization experiments to look for the possible presence of more groEL-like genes in the $S$. lividans genome. The 217 bp B2-A1 DNA fragment from plasmid pPLVG1 (Fig. 1) was used as a probe specific for groES. The $244 \mathrm{bp}$ Sm-A1 DNA fragment from plasmid pPLVG2 (Fig. 1) was used as a probe specific for groEL2. 


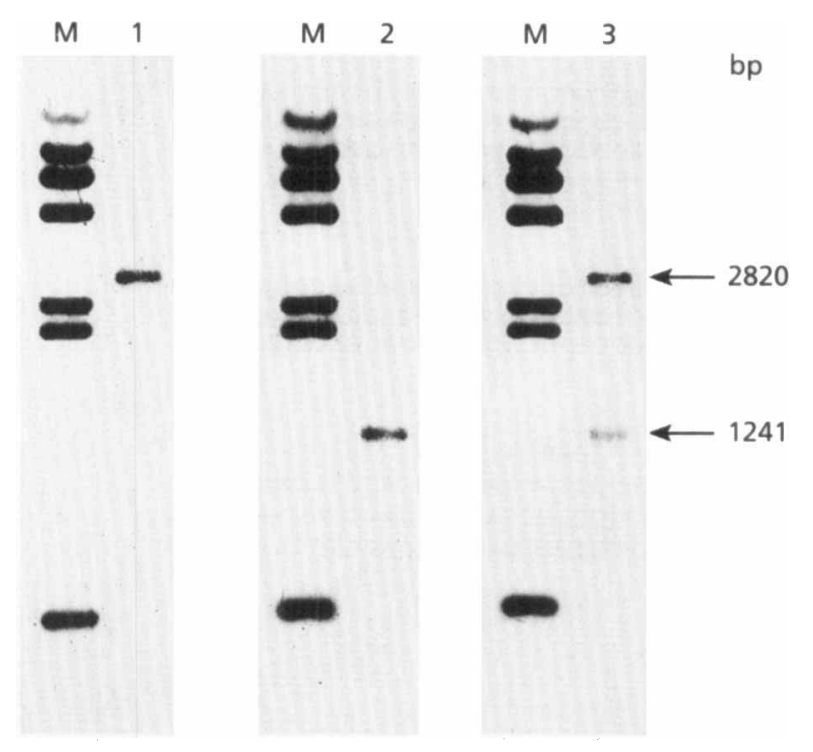

Fig. 3. Genomic blot hybridization. DNA probes specific for groES (lane 1), groEL2 (lane 2) and groEL1-groEL2 (lane 3) were used to hybridize S. lividans genomic DNA restricted with Sall. Radioactively labelled HindIII fragments from bacteriophage $\lambda$ DNA were used as size markers (lanes $M$ ). Numbers on the right indicate the molecular size of the DNA fragments giving positive hybridization signals.

A third probe specific for both groEL1 and groEL2 was the 374 bp DNA fragment resulting from several cycles of PCR amplification of the $S$. lividans genome using the oligonucleotides Gro-1 (CCGATCGACGAGAAGTCCGAC) and Gro-2 (GGAGAGCGCCTCGCCCTCCAGG) as primers. Sall was chosen to restrict $S$. lividans genomic DNA. The results of the Southern blot hybridization are shown in Fig. 3. Unique DNA fragments of 2820 and $1241 \mathrm{bp}$ (Fig. 3, lanes 1 and 2) hybridized to the groES- and groEL2-specific probes, respectively; the same two DNA fragments also hybridized to the probe specific for both groEL1 and groEL2 (Fig. 3, lane 3), strongly suggesting that $S$. lividans DNA does not contain more than two groEL-like genes.

\section{Transcription initiation}

Transcription initiation sites for groES/EL1 and groEL2 were determined by high resolution S1 nuclease protection experiments. S1 mapping experiments were performed with appropriate single-stranded probes, using total RNA extracted as described in Methods.

Transcription initiation from groES/EL1 was mapped using the single-stranded HindIII-AvaI fragment (H1$\mathrm{A} 1$ in pPLVG1b, Fig. 1), purified as described by Barthelemy et al. (1986) and labelled at its AvaI 5' end, as a probe. This fragment was obtained from the digestion of a PCR fragment (obtained from the amplification of $S$. lividans genomic DNA using oligonucleotides $\mathrm{N}^{*}$-PES and R-PES as primers; $\mathrm{H} 1-\mathrm{H} 2$ in
pPLVG1a, Fig. 1) with HindIII and AvaI. Transcription initiation from groEL2 was mapped using the singlestranded Smal-AvaI fragment (Sm-A1, Fig. 1), purified as described by Barthelemy et al. (1986) and labelled at its Aval 5' end, as a probe.

Transcription initiated from unique start sites at $197 \mathrm{nt}$ from the 5'-labelled AvaI end in the case of groEL2 (Fig. $4 \mathrm{~b})$ and at $166 \mathrm{nt}$ from the $5^{\prime}$-labelled $A v a \mathrm{I}$ end in the case of groES/EL1 (Fig. 4a). Transcription was subjected to temporal control at $30^{\circ} \mathrm{C}$, as it decreased when the culture entered stationary phase. Under heat shock conditions the amount of the groEL2 transcript was approximately tenfold higher than that of groES/EL1, as determined by densitometry of the S1-protected radioactive fragments, corrected by the exposure time of the gels. In addition, transcription from groEL2 also showed a dramatic increase at $45^{\circ} \mathrm{C}$, about tenfold higher than transcription at $30^{\circ} \mathrm{C}$ (Fig. $4 \mathrm{c}$ ).

\section{Partial characterization of the heat-induced GroEL complex}

After a $15 \mathrm{~min}$ heat shock, exponentially growing $S$. lividans TK21 cells were lysed and most of the soluble protein adhered to DEAE-cellulose (Fig. 5, lanes 1-3). The main component that remained unbound to the resin had a relative mobility very similar to the GroEL peptide $(60 \mathrm{kDa})$ from $E$. coli. When this material was subjected to centrifugation in a sucrose gradient, fractions corresponding to a sedimentation coefficient around $20 S$ showed a protein pattern composed mainly of this peptide (Fig. 5, lane 4), suggesting that it is assembled in a multimeric complex.

The $62 \mathrm{kDa}$ peptide from the gradient-enriched sample showed a clear cross-reaction against a polyclonal serum specific for GroEL from E. coli (Fig. 6). The specific reactivity of the $S$. lividans peptide was similar to that of the homologous GroEL and clearly different from a control protein of similar molecular size, glutamine synthetase (EC 6.3.1.2; Fig. 6).

\section{Partial sequencing of the purified protein and chaperonin folding activity}

As an additional characterization of the $S$. lividans $62 \mathrm{kDa}$ fraction, a sample from the sucrose-gradientpurified material was subjected to trypsin digestion. Two resulting peptides were sequenced and the resulting amino acid sequences compared to those derived from the nucleotide data from S. lividans groEL1 and groEL 2 coding sequences. In both cases the alignment matched clearly with GroEL2, strongly suggesting that the fraction produced under heat shock conditions, predominantly enriched in the $62 \mathrm{kDa}$ polypeptide, was actually derived from the GroEL2 protein of S. lividans (Fig. 7).

Chaperonin folding activity from the $62 \mathrm{kDa}$ peptide from the gradient-enriched sample was measured as 
(a)

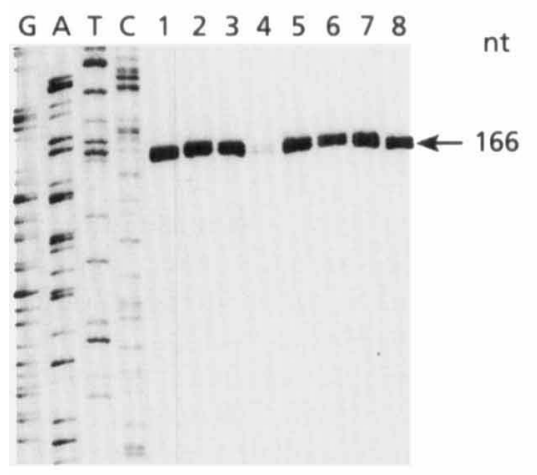

(b)

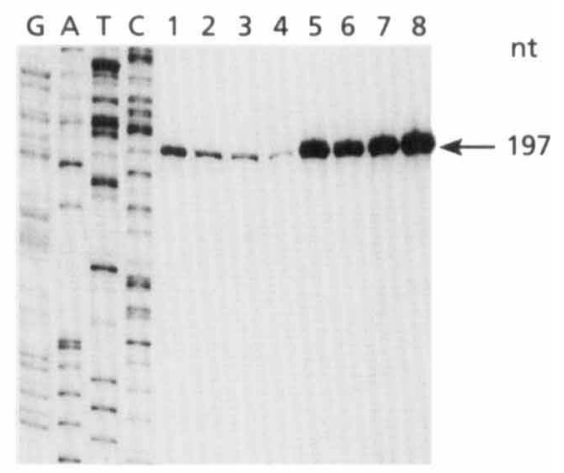

Fig. 4. Determination of transcriptional start sites of the groES/EL1 operon (a) and groEL2 (b) by $\mathrm{S} 1$ mapping. Total RNAs were isolated from cultures at various times of growth: $19 \mathrm{~h}$ (lanes 1 and 5), $23 \mathrm{~h}$ ( 2 and 6), $27 \mathrm{~h}$ ( 3 and 7) and $42 \mathrm{~h}(4$ and 8$)$ at $30^{\circ} \mathrm{C}(1-4)$ or after a $15 \mathrm{~min}$ shift to $45^{\circ} \mathrm{C}$ at the same times (5-8). Unique transcription initiation start sites are indicated by arrows. Sequence ladders, run in parallel, from the known DNA sequence of pPLVG1a (starting at $\mathrm{H} 1$ and progressing to $\mathrm{H} 2$; Fig. 1) are shown. (c) The variation in the different groEL transcripts during the culture growth. Values given correspond to arbitrary integration units $(U)$ of the S1-protected fragments corrected by the exposure time of the autoradiographs. 0,O, groES/EL transcription at 45 and $30^{\circ} \mathrm{C}$, respectively. $\square, \square$, groEL2 transcription at 45 and $30^{\circ} \mathrm{C}$, respectively.

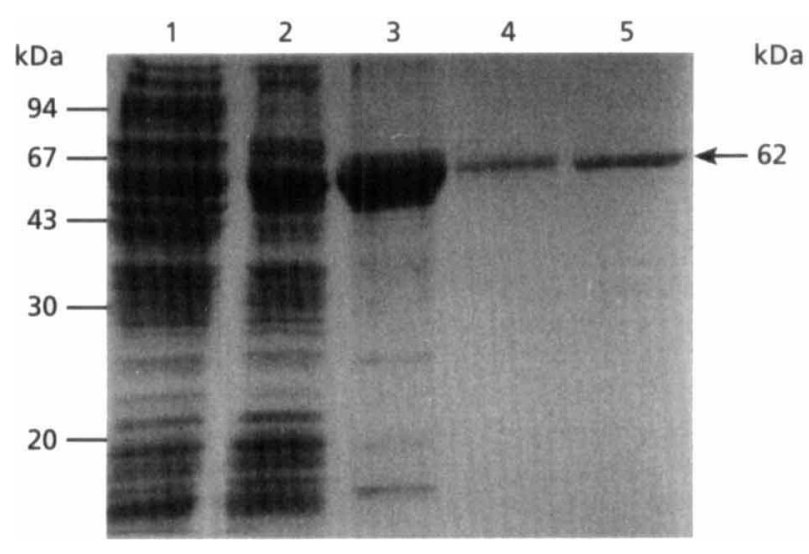

Fig. 5. GroEL2 purification. Polyacrylamide gel $(12.5 \%$, w/v) showing the protein analysed at different stages of purification. Lanes: 1, lysed culture; 2, lysed culture supernatant; 3 , protein unbound to DEAE-cellulose; 4 , sucrose gradient fraction containing the purified protein; 5, GroEL protein from $E$. coli. The arrow indicates the presence of a $62 \mathrm{kDa}$ protein.

described in the legend to Table 1 . The $62 \mathrm{kDa}$ fraction (GroEL2 from S. lividans) exhibited a folding activity very similar to that obtained with GroEL and GroES from E. coli, even though in the S. lividans GroEL2

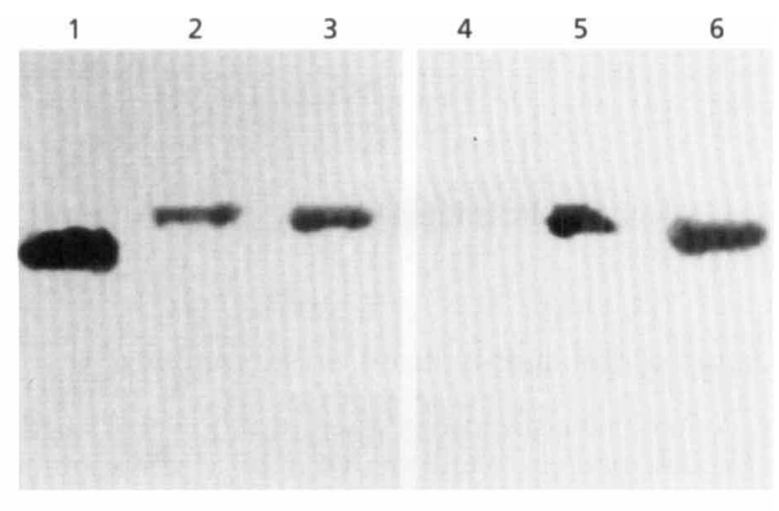

Fig. 6. Protein blotting and parallel electrophoresis. A fraction from the sucrose gradient containing the $62 \mathrm{kDa}$ protein from S. lividans (lane 2) was analysed by SDS-PAGE together with glutamine synthetase (lane 1) and $E$. coli GroEL (lane 3). They were subjected to a Western blotting assay using antibodies raised against $E$. coli GroEL; the reactions with glutamine synthetase (lane 4), S. lividans $62 \mathrm{kDa}$ protein (lane 5) and $E$. coli GroEL (lane 6) are shown.

fraction there was no noticeable co-chaperonin. This behaviour is different to that of the E. coli GroEL, the folding activity of which is fully dependent of the presence of the co-chaperonin GroES. Interestingly, when the E. coli GroES was added to the S. lividans 


$$
\begin{array}{cc}
\text { GroEL1 s.lividans } & \text { 1..MAKILKFDEDARRAL ..15 } \\
\text { GroEL2 s.lividans } & 1 \ldots \text { MAKIIAFDELARRGL..15 } \\
\text { peptide A } & 1 \ldots \text { IIAFDXXA.....8 }
\end{array}
$$

GroEL1 S.lividans

54. . IAREVEVEDPYENLG . .68

GroEL2 S.lividans

55. . IAKEIELEDPYEKIG. . 69

peptide $B$

$$
1 \ldots \text { EIELEDPYEK. . . } 10
$$

Fig. 7. Comparison of the S. lividans GroEL1 and GroEL2 deduced amino acid sequences with those obtained from internal peptides of the $62 \mathrm{kDa}$ purified protein. Numbers indicate the relative amino acid positions within the sequences. Identical amino acids are indicated in bold.

Table 1. Chaperonin-like folding activity of the fraction enriched in the $62 \mathrm{kDa}$ protein

Chaperonin folding activity was assayed at $37^{\circ} \mathrm{C}$ for $40 \mathrm{~min}$ and measured as described by Llorca et al. (1994). Values represent the mean of three measurements.

\begin{tabular}{|lc|}
\hline Sample & $\begin{array}{c}\text { Activity } \\
\text { (OD units/\%) }\end{array}$ \\
\hline E. coli GroEL +E. coli GroES & $0 \cdot 151 / 100$ \\
E. coli GroEL & $0 \cdot 001 / 0 \cdot 7$ \\
S. lividans GroEL2 & $0 \cdot 155 / 103$ \\
S. lividans GroEL2 + E. coli GroES & $0 \cdot 052 / 34$ \\
\hline
\end{tabular}

GroEL2 fraction, the folding activity dropped almost by $60 \%$.

\section{Structure of the heat-induced GroEL complex}

Samples from the sucrose gradient fractions enriched in the $62 \mathrm{kDa}$ protein were analysed by electron microscopy. Micrographs revealed the presence of two main particles (Fig. 8). The most abundant one had a rectangular shape with dimensions $15 \times 10 \mathrm{~nm}$, showing lateral indentations and a stain-penetrated striation along the centre of the particle. The other had a doughnut shape, with a central stained region and a diameter around $15 \mathrm{~nm}$. Due to their similar dimensions, both images could be derived from the same particle, corresponding to lateral and end-on views, respectively, as seen in the Hsp60 GroEL particles from E. coli and Bacillus subtilis (Martin \& Hartl, 1997; Carrascosa et al., 1990). Nevertheless, the morphology and dimensions of the $S$. lividans particle are more similar to the single ring particle produced by the $E$. coli GroEL mutant SR1 (Weissman et al., 1996) than to the usual two-ring structure that is characteristic of the common Hsp60
GroEL. The single toroidal structure is also reminiscent of the morphology of the mammalian chaperonin 60 (Viitanen et al., 1992).

\section{DISCUSSION}

In $S$. lividans there are two groEL homologues, a characteristic that seems to be shared by other actinomycetes including $S$. albus and S. coelicolor (Mazodier et al., 1991; Duchene et al., 1994a) as well as by some Mycobacterium and Synechocystis species (Rinke de Wit et al., 1992; Lehel et al., 1993). More than two groEL homologues have been described for Sinorbizobium (Rhizobium) meliloti (Rusanganwa \& Gupta, 1993) and Rhizobium leguminosarum (Wallington \& Lund, 1994). The nitrogen fixing soybean root nodule bacterium, Bradyrhizobium japonicum, possesses a multigene family consisting of five groESL-like genes and this bacterium may control its GroES and GroEL content in response to specific environmental and physiological needs (Fischer et al., 1993), a feature that might be shared by the other bacteria.

In response to a temperature shift, transcription of both groES/EL1 and groEL2 from S. lividans occurs at high temperature, but the level of groEL2 transcription seems to be considerably higher. The upstream regulatory regions from both groES/EL1 and groEL2 showed $98 \%$ homology to those of S. coelicolor (Duchene et al., 1994a). The regions upstream from groES/EL1 and groEL2 are also similar to those of $S$. albus (Mazodier et al., 1991) as the homology between them is $93 \%$ and $85 \%$, respectively (Fig. 2). It has been reported that the vegetative $\sigma$ factor, $\mathrm{HrdB}$, would be the regulatory protein involved in controlling the expression of the $S$. coelicolor groEL genes (Duchene et al., 1994b). In the case of $S$. lividans, both promoters could also be subjected to control by the equivalent $S$. lividans $\mathrm{HrdB}$ since both of them have -10 and -35 regions which are homologous to those of $S$. coelicolor and to the consensus sequence for vegetative promoters in Streptomyces (Strohl, 1992; Fig. 2).

The highly conserved inverted repeat GCACTCN $\mathrm{H}_{9} \mathrm{GA}$ GTGC, designated CIRCE, has also been described upstream of groEL and $d n a K$ genes of many bacteria including groESL4 from B. japonicum (Babst et al., 1996; Zuber \& Schumann, 1994), suggesting that CIRCE elements may play a role in heat shock regulation of these genes. This region appears to be a DNA recognition site, acting as an operator for the dnaK operons of B. subtilis and S. coelicolor (Shulz \& Schumann, 1996; Segal \& Ron, 1996). If a similar mechanism operated in S. lividans to allow transcription of the groEL genes after the temperature shift, another regulatory element such as an activator may be required to account for the tenfold increase of groEL2 transcription at $45^{\circ} \mathrm{C}$. Post-transcriptional regulation may also occur, either through direct control of mRNA stability or by regulation of translation. Post-transcriptional regulatory signals needed for heat-induced 


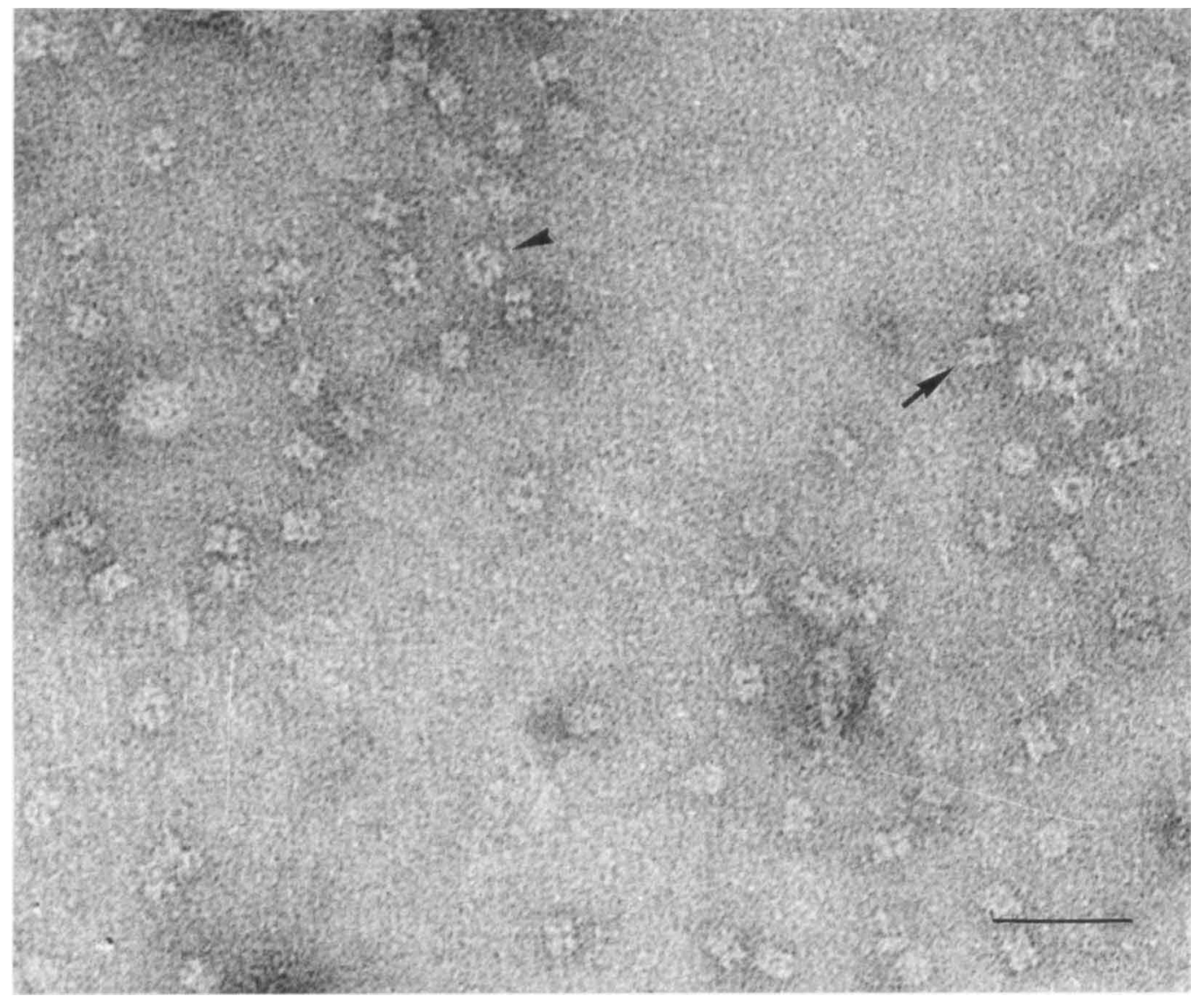

Fig. 8. Representative electron micrograph of a field of samples from the sucrose gradient containing the $62 \mathrm{kDa}$ protein. The arrowhead points to the front view and the arrow to the side view. Bar, $50 \mathrm{~nm}$.

GroEL1 synthesis have been mapped within the groEL1 structural gene of $S$. coelicolor (Servant et al., 1994) and $S$. albus produces three GroEL-like proteins, Hsp56 (GroEL2), Hsp58 (GroEL1) and Hsp18 whose Nterminal amino acid sequence is identical to that of Hsp58 (Guglielmi et al., 1993). Both groEL genes from $S$. albus have been mutagenized by gene disruption in the chromosome and the conclusion of this experiment is that the N-terminal part of groEL1 encoding Hsp18 and the whole of groEL2 encoding Hsp56 seem to be essential for growth (Servant et al., 1993). GroEL1 post-transcriptional regulation is likely to occur in S. lividans as well, as deduced from the conserved amino acid sequences of the S. lividans, S. coelicolor and S. albus GroEL1 proteins.

Among the proteins synthesized by S. lividans under heat shock, we were able to isolate a fraction enriched in a $62 \mathrm{kDa}$ protein. This protein cross-reacted with antibodies raised against GroEL from E. coli, and two internal peptides produced by trypsin digestion matched with sequences of GroEL2 from S. lividans. The sedimentation behaviour of this fraction revealed that the protein was assembled as a multimeric particle with a morphology that closely resembled that of the single ring Hsp60 chaperonins (Viitanen et al., 1992; Weissman et al., 1996). The GroEL2 enriched fraction showed a chaperonin-like peptide folding activity, suggesting that the GroEL2 chaperonin activity may not require the presence of a co-chaperonin. Alternatively, possible non-detectable contaminant amounts of co-chaperonin present in the fraction may be sufficient for the folding reaction. In any case, the folding activity was significantly reduced in the presence of the GroES cochaperonin from $E$. coli, perhaps indicating a possible competitive interaction between the $E$. coli co-chaperonin and the substrate for the $S$. lividans $62 \mathrm{kDa}$ chaperonin. The presence of a genuine co-chaperonin from $S$. lividans, although not detected in our analysis, cannot be ruled out; therefore, competitive interaction between E. coli and S. lividans co-chaperonins might also lead to a decrease in folding activity. A more highly purified fraction and a higher yield of the $62 \mathrm{kDa}$ protein, as well as purified GroES from S. lividans are needed to characterize properly both the folding activity (and ATP dependence) and the final structure of the $S$. lividans GroEL2 chaperonin. Comparative studies involving GroEL1 and GroEL2 should shed more light on the physiological role played by the two chaperonins in streptomycete cellular metabolism. 


\section{ACKNOWLEDGEMENTS}

We thank J. Vázquez for his supervision on the protein sequencing. P.L. and C.I. are recipients of fellowships from the Comunidad de Madrid and from the Spanish PFPI, respectively. This research was supported by Grant BIO940792 from the Spanish CICYT.

\section{REFERENCES}

Babst, M., Hennecke, H. \& Fisher, H. M. (1996). Two different mechanisms are involved in the heat-shock regulation of chaperonin gene expression in Bradyrhizobium japonicum. Mol Microbiol 19, 827-839.

Barthelemy, I., Salas, M. \& Mellado, R. P. (1986). In vivo transcription of bacteriophage $\phi 29$ DNA : transcription initiation sites. J Virol 60, 874-879.

Berdy, J. (1980). Recent advances in and prospects of antibiotic research. Process Biochem Oct/Nov, 28-35.

Carazo, J. M., Marco, S., Abella, G., Carrascosa, J. L., Secilla, J. P. \& Muyal, M. (1991). Electron microscopy study of GroEL chaperonin: different views of the aggregate appear as a function of cell growth temperature. J Struct Biol 106, 211-220.

Carrascosa, J. L., Abella, G., Marco, S. \& Carazo, J. M. (1990). Three-dimensional reconstruction of the sevenfolded form of Bacillus subtilis GroEL chaperonin. J Struct Biol 104, 2-8.

Chater, K. F. (1984). Morphological and Physiological Differentiation in Streptomyces. Cold Spring Harbor, NY: Cold Spring Harbor Laboratory.

Craig, E. A., Gambill, B. D. \& Nelson, R. J. (1993). Heat shock proteins: molecular chaperones of protein biogenesis. Microbiol Rev 57, 402-414.

Duchene, A.-M., Kieser, H. M., Hopwood, D. A., Thompson, C. J. \& Mazodier, P. (1994a). Characterization of two groEL genes in Streptomyces coelicolor A3(2). Gene 144, 97-101.

Duchene, A.-M., Thompson, C. J. \& Mazodier, P. (1994b). Transcriptional analysis of groEL genes in Streptomyces coelicolor A3 (2). Mol Gen Genet 245, 61-68.

Favaloro, J., Treiman, R. \& Kamen, R. (1980). Transcription maps of polyoma virus-specific RNA : analysis by two dimensional S1 gel mapping. Methods Enzymol 65, 718-749.

Fischer, H. M., Babst, M., Kaspar, T., Acuńa, G., Arigoni, F. \& Hennecke, H. (1993). One member of a groESL-like chaperonin multigene family in Bradyrhizobium japonicum is co-regulated with symbiotic nitrogen fixation genes. EMBO J 12, 2901-2912.

Guglielmi, G., Duchene, A.-M., Thompson, C. \& Mazodier, P. (1993). Transcriptional analysis of two different Streptomyces albus groEL-like genes. In Industrial Microorganisms: Basic and Applied Molecular Genetics, pp. 17-24. Edited by R. H. Baltz, G. D. Hegeman \& P. L. Skatrud. Washington, DC: American Society for Microbiology.

Hanahan, D. (1983). Studies on transformation of Escherichia coli with plasmids. $J$ Mol Biol 166, 557-580.

Hopwood, D. A., Bibb, M. J., Chater, K. F., Kieser, T., Bruton, C. J., Kieser, H. M., Lydiate, D. J., Smith, C. P., Ward, J. M. \& Schrempf, H. (1985). Genetic Manipulation of Streptomyces: a Laboratory Manual. Norwich: John Innes Foundation.

Hu, P., Chase, T., Jr \& Eveleigh, D. E. (1993). Cloning of Microbispora bispora cellobiohydrolase gene in Streptomyces lividans. Appl Microbiol Biotechnol 38, 631-637.
Kieser, T. \& Hopwood, D. A. (1991). Genetic manipulation of Streptomyces: integrating vectors and gene replacement. Methods Enzymol 204, 430-458.

Laemmli, U. K. (1970). Cleavage of structural proteins during the assembly of the head of bacteriophage T4. Nature 227, 680-685.

Lehel, C., Los, D., Wada, H., Gyorgyei, J., Horváth, I., Kovács, E., Murata, N. \& Vigh, L. (1993). A second groEL-like gene, organized in a groESL operon is present in the genome of Synechocystis sp. PCC6803. J Biol Chem 268, 1799-1804.

Llorca, O., Marco, S., Carrascosa, J. L. \& Valpuesta, J. M. (1994). The formation of symmetrical GroEL-GroES complexes in the presence of ATP. FEBS Lett 345, 181-186.

Marco, S., Parro, V., Carrascosa, J. L. \& Mellado, R. P. (1992). Streptomyces lividans possesses a GroEL-like chaperonin. FEMS Microbiol Lett 93, 127-132.

Martin, J. \& Hartl, F. U. (1997). Chaperone assisted folding. Curr Opin Struct Biol 7, 41-52.

Mazodier, P., Guglielmi, G., Davies, J. \& Thompson, C. J. (1991). Characterization of the groEL-like genes in Streptomyces albus. $J$ Bacteriol 173, 7382-7386.

Murray, N. E. (1983). Phage lambda and molecular cloning. In Lambda II, pp. 395-431. Edited by R. W. Hendrix, J. W. Roberts, F. W. Stahl \& R. A. Weisberg. Cold Spring Harbor, NY: Cold Spring Harbor Laboratory.

Norrander, J., Kempe, T. \& Messing, J. (1983). Construction of improved M13 vectors using oligodeoxynucleotide-directed mutagenesis. Gene 26, 101-106.

Parro, V., Hopwood, D. A., Malpartida, F. \& Mellado, R. P. (1991). Transcription of genes involved in the earliest steps of actinorhodin biosynthesis in Streptomyces coelicolor. Nucleic Acids Res 19, 2623-2627.

Puglia, A.-M., Vohradsky, J. \& Thompson, C. J. (1995). Developmental control of the heat-shock stress regulon in Streptomyces coelicolor. Mol Microbiol 17, 737-746.

Pulido, D., Jimenez, A., Salas, M. \& Mellado, R. P. (1987). A Bacillus subtilis phage $\phi 29$ transcription terminator is efficiently recognized in Streptomyces lividans. Gene 56, 277-282.

Rinke de Wit, T. F., Bekelie, S., Osland, A., Miko, T. L., Hermans, P. W. M., Van Soolingen, D., Drijfhout, J. W., Schöningh, R., Janson, A. A. M. \& Thole, J. E. R. (1992). Mycobacteria contain two groEL genes: the second Mycobacterium leprae groEL gene is arranged in an operon with groES. Mol Microbiol 6, 1995-2007.

Rosenfeld, J., Capdeville, J., Guillemot, J. C. \& Ferrara, P. (1992). In-gel digestion of proteins for internal sequence analysis after one or two-dimensional gel electrophoresis. Anal Biochem 203, 173-179.

Rusanganwa, E. \& Gupta, R. S. (1993). Cloning and characterization of multiple groEL chaperonin-encoding genes in Rbizobium meliloti. Gene 126, 67-75.

Sambrook, J., Fritsch, E. F. \& Maniatis, T. (1989). Molecular Cloning: a Laboratory Manual, 2nd edn. Cold Spring Harbor, NY: Cold Spring Harbor Laboratory.

Sanger, F., Nicklen, S. \& Coulson, A. R. (1977). DNA sequencing with chain-terminating inhibitors. Proc Natl Acad Sci USA 74, 5463-5467.

Segal, G. \& Ron, E. R. (1996). Regulation and organization of the groE and dnaK operons in Eubacteria. FEMS Microbiol Lett 138, $1-10$.

Servant, P., Thompson, C. \& Mazodier, P. (1993). Use of new 
Escherichia coli/Streptomyces conjugative vectors to probe the functions of the two groEL-like genes of Streptomyces albus $\mathrm{G}$ by gene disruption. Gene 134, 25-32.

Servant, P., Thompson, C. J. \& Mazodier, P. (1994). Posttranscriptional regulation of the groEL1 gene of Streptomyces albus. Mol Microbiol 12, 423-432.

Shulz, A. \& Schumann, W. (1996). hrcA, the first gene of the Bacillus subtilis dnaK operon encodes a negative regulator of Class I heat shock genes. J Bacteriol 178, 1088-1093.

Sollner-Webb, B. \& Reeder, R. H. (1979). The nucleotide sequence of initiation and termination sites for ribosomal RNA transcription in X. laevis. Cell 18, 485-499.

Stone, K. L. \& Williams, K. R. (1993). Enzymatic digestion of proteins and HPLC peptide isolation. In A Practical Guide to Protein and Peptide Purification for Microsequencing, pp. 43-69. Edited by P. Matsuda. New York: Academic Press.

Strickler, J. E., Berka, T. R., Gorniak, J., Fornwald, J., Keys, R., Rowland, J. J., Rosenberg, M. \& Taylor, D. P. (1992). Two novel Streptomyces protein protease inhibitors. J Biol Chem 267, 3236-3241.

Strohl, W. R. (1992). Compilation and analysis of DNA sequences associated with apparent streptomycete promoters. Nucleic Acids Res 20, 961-974.
Timmons, T. M. \& Dunbar, B. S. (1990). Protein blotting and immunodetection. Methods Enzymol 182, 679-688.

Viitanen, P. V., Lorimer, G. H., Seethram, R., Gupta, R. S., Oppenheim, J., Thomas, J. O. \& Cowan, N. J. (1992). Mammalian mitochondrial chaperonin 60 functions as a single toroidal ring. J Biol Chem 267, 695-698.

Wallington, E. J. \& Lund, P. A. (1994). R hizobium leguminosarum contains multiple chaperonin (cpn60) genes. Microbiology 140, 113-122.

Weissman, J. S., Rye, H. S., Fenton, W. A., Beechem, J. M. \& Horwich, A. L. (1996). Characterization of the active intermediate of a GroEL-GroES-mediated protein folding reaction. Cell 84, $481-490$.

Westly, J. (1981). Thiosulfate:cyanide sulfurtransferase (rhodanase). Methods Enzymol 77, 285-291.

Wright, F. \& Bibb, M. J. (1992). Codon usage in the $G+C$ rich Streptomyces genome. Gene 113, 55-65.

Zuber, U. \& Schumann, W. (1994). CIRCE, a novel heat shock element involved in regulation of heat shock operon $d n a K$ of Bacillus subtilis. J Bacteriol 176, 1359-1363.

Received 6 June 1997; accepted 23 July 1997. 